\title{
Bringing a research base to psychiatry
}

I $\mathrm{n}$ this era of evidence-based medicine, the scarcity of high-quality evidence for mental health care is striking. Mental health practitioners often cannot obtain useful information to guide their clinical decisions, a situation that the director of the US National Institutes of Mental Health described as "the unfortunate current state" in psychiatry, "where too many research studies have little immediate relevance to practice, and too little practice is based on research evidence." ${ }^{1}$ This weak foundation impacts the treatment of schizophrenia and bipolar disorder, which each affect about $\mathrm{I} \%$ of the population (300 000 Canadians), and depression, which will affect about $8 \%$ of Canadians during the course of their lives. What does this mean for patients?

In this issue, Deshauer and colleagues highlight the fact that trials of antidepressants are typically too short to be meaningful. ${ }^{2}$ Trials of psychiatric medications have also been criticized for playing down the adverse effects or potential for abuse of drugs being tested, ${ }^{3,4}$ and in pediatrics, large-scale trials of atypical antipsychotic drugs simply do not exist. ${ }^{5}$ Despite this lack of evidence, the overwhelming majority of developmental pediatricians and child psychiatrists in Canada prescribe these drugs anyway. ${ }^{6}$ The situation is not much better for adults. Atypical antipsychotics are a mainstay of treatment of schizophrenia, but many head-to-head trials of these drugs have been judged unreliable: "It appears that whichever company sponsors the trial produces the best drug," wrote the authors of a 2006 analysis.

However, there is an ongoing effort to transform the evidence base in this field. Spearheaded by the US National Institutes of Health after its success with similar efforts in cardiology and oncology, the strategy involves developing networks of clinicians at many different centres following hundreds of patients in large-scale definitive trials. ${ }^{8}$ A network funded by the National Institutes of Health evaluated the effectiveness of pharmacologic treatments for depression in the Sequenced Treatment Alternatives to Relieve Depression (STAR ${ }^{\star} \mathrm{D}$ ) trial, which Rush writes in this issue. ${ }^{9}$ National Institutes of Health networks are also examining bipolar disorder, schizophrenia, adolescent depression and Alzheimer disease. ${ }^{10-16}$ A network in the United Kingdom, funded by the Stanley Medical Research Institute, is studying the use of mood stabilizing drugs in bipolar disorder, ${ }^{17}$ a UK National Health Service network has examined drug treatments for schizophrenia, ${ }^{18}$ and an industry-sponsored network of 50 centres in Europe and Israel has assessed antipsychotic treatment for young people in the earliest stages of schizophrenia. ${ }^{19}$

Reports from these "pragmatic" or "practical" trials have only just begun to emerge in the past 2-3 years, but they have the potential to change practice in important ways. The National Institutes of Health and UK trials of schizophrenia treatment (Clinical Antipsychotic Trials of Intervention Effectiveness [CATIE], Cost Utility of the Latest Antipsychotic Drugs in Schizophrenia Study [CUtLASS]) both found that the newer, atypical antipsychotics offer little advantage over first-generation antipsychotics, results so shocking that an editorial about them was titled "CATIE and CUtLASS: Can we handle the truth?"20

We expect that psychiatrists will welcome the "truth" that such definitive trials provide, just as these types of trials in cardiology, many performed in Canada, have led to improvements in care. But important questions remain unanswered. The United States, Europe and the United Kingdom have shown the way forward by focusing their efforts on comparing clinically important outcomes in large-scale, naturalistic settings. Canada should be part of the process, even leading it in areas where our researchers have established expertise. Without a forceful push, large-scale randomized trials in psychiatry will not become a priority. So where do we start?

The Mental Health Commission of Canada, launched in August 2007 under Senator Michael Kirby, received \$IIo million in the 2008 federal budget. This commission should play a crucial role in bringing attention to the knowledge deficit and advocating for researchers to address it. Another first step is for the Canadian Institutes of Health Research to tackle the challenge of developing and maintaining networks of clinicians who can conduct large-scale trials in psychiatry. Dr. Alain Beaudet, who becomes president of Canadian Institutes of Health Research in July 2008, might well consider that scientific leadership at the national level is required to get such trials off the ground. In the United States, the head of the National Institutes of Health has made large-scale trials part of the institute's "road map," and the head of the National Institute of Mental Health promoted these trial as a means of closing the gap between research and practice in psychiatry. ${ }^{1,21}$ Canadian researchers in psychiatry deserve similar inspiration and support in the form of clear financial commitments.

In the current state of limited or missing evidence, mental health professionals can only guess at best treatments. What this means for patients is that their doctors do not know which treatments will likely work and which will likely fail for any given person with a mental disorder. Psychiatry needs to integrate research into care by conducting large-scale trials and implementing the results. For mental illness, as for medical diseases, our best should be more than a guess.

\section{Miriam Shuchman MD}

Associate Professor of Psychiatry

University of Toronto

Women's College Hospital

Toronto, Ont.

Paul C. Hébert MD MHSc

Editor-in-chief, CMAJ

With the Editorial-Writing Team (Rajendra Kale MD,

Barbara Sibbald BJ, Ken Flegel MDCM MSc and

Noni MacDonald MD MSc) 
FRANÇAIS À LA PAGE SUIVANTE

Competing interests: None declared for Miriam Shuchman. None declared for Paul Hébert concerning this editorial; for further details, see www.cmaj.ca/misc/edboard.shtml. See www.cmaj.ca/misc/edboard.shtml for the Editorial-Writing Team's statements.

\section{REFERENCES}

I. Insel TR. Beyond efficacy: the STAR ${ }^{\star} \mathrm{D}$ trial. Am J Psychiatry 2006;163:5-7.

2. Deshauer D, Moher D, Fergusson D, et al. Selective serotonin reuptake inhibitors for unipolar depression: a systematic review of classic long-term randomized controlled trials. CMAJ 2008;178:1293-30I.

3. Kruszewski SP. Euphorigenic and abusive properties of modafinil. Am J Psychiatry 2006;163:549.

4. Kruszewski SP, Klotz SG. Effects of topiramate. Am J Psychiatry 2007;I64:526-7.

5. McClellan JM. Olanzapine and pediatric bipolar disorder: evidence for efficacy and safety concerns. Am J Psychiatry 2007;164:I462-4.

6. Doey T, Handelman K, Seabrook JA, et al. Survey of atypical antipsychotic prescribing by Canadian child psychiatrists and developmental pediatricians for patients aged under I8 years. Can J Psychiatry 2007;52:363-8.

7. Heres S, Davis J, Maino K, et al. Why olanzapine beats risperidone, risperidone beats quetiapine, and quetiapine beats olanzapine: an exploratory analysis of headto-head comparison studies of second-generation antipsychotics. Am J Psychiatry 2006;163:185-94.

8. March JS, Silva SG, Compton S, et al. The case for practical clinical trials in psychiatry. Am J Psychiatry 2005;162:836-46.

9. Rush AJ. Developing the evidence for evidence-based practice. CMAJ 2008;178 I3I $3-5$.

Io. Lieberman JA, Stroup TS, McEvoy JP, et al. Effectiveness of antipsychotic drugs in patients with chronic schizophrenia. N Engl J Med 2005;353:1209-23.

II. Rosenheck RA, Leslie DL, Sindelar J, et al. Cost-effectiveness of second generation antipsychotics and perphenazine in a randomized trial of treatment for chronic schizophrenia. Am J Psychiatry 2006;163:2080-9.

I2. Schneider LS, Tariot PN, Dagerman KS, et al. Effectiveness of atypical antipsychotic drugs in patients with Alzheimer's disease. N Engl J Med 2006;355: I525-38.

I3. Rush AJ, Trivedi MH, Wisniewski SR, et al. Acute and longer-term outcomes in depressed outpatients who required one or several treatment steps: a STAR ${ }^{D}$ report. Am J Psychiatry 2006;163:1905-17.

I4. Sachs GS, Nierenberg AA, Calabrese JR, et al. Effectiveness of adjunctive antidepressant treatment for bipolar depression. N Engl J Med 2007;356:I7II-22.

I5. March JS, Silva S, Petrycki S, et al. The Treatment for Adolescents with Depression Study (TADS): long-term effectiveness and safety outcomes. Arch Gen Psychiatry 2007;64:1132-43.

I6. Brent D, Emslie G, Clark G, et al. Switching to another SSRI or to venlafaxine with or without cognitive behavioral therapy for adolescents with SSRI-resistant depression: the TORDIA randomized controlled trial. JAMA 2008;299:90I-I3.

I7. Geddes J, Goodwin G, Rendell J, et al. New trial should clarify lithium use in bipolar disorder. $B M J$ 2002;325:44I.

I8. Jones PB, Barnes TR, Davies L, et al. Randomized controlled trial of the effect on quality of life of second- vs first-generation antipsychotic drugs in schizophrenia: Cost Utility of the Latest Antipsychotic Drugs in Schizophrenia Study (CUtLASS I). Arch Gen Psychiatry 2006;63:1079-87.

I9. Kahn RS, Fleischhacker WW, Boter $\mathrm{H}$, et al. Effectiveness of antipsychotic drugs in first-episode schizophrenia and schizophreniform disorder: an open randomized clinical trial. Lancet 2008;371:1085-97.

20. Lewis S, Lieberman J. CATIE and CUtLASS: can we handle the truth? BrJ Psychiatry 2008;I92:I6I-3.

2I. Zerhouni E. The NIH Roadmap. Science 2003;302:63-72. 